\title{
Non-Sterile Augur Powder Filling Method
}

National Cancer Institute

\section{Source}

National Cancer Institute. Non-Sterile Augur Powder Filling Method. NCI Thesaurus. Code C112991.

A process that fills a dosage unit using an augur to deliver the powder, which is not performed under sterile conditions. 